\title{
Palladium(II)-catalyzed Heck reaction of aryl halides and arylboronic acids with olefins under mild conditions
}

\author{
Tanveer Mahamadali Shaikh and Fung-E Hong*
}

\author{
Full Research Paper \\ Address: \\ Department of Chemistry, National Chung Hsing University, 250 \\ Kuo-Kuang Road, Taichung, Taiwan (R.O.C.) \\ Email: \\ Fung-E Hong* - fehong@dragon.nchu.edu.tw \\ * Corresponding author \\ Keywords: \\ aryl halides; Heck reaction; olefins; palladium-complex; phosphine
}

\author{
Beilstein J. Org. Chem. 2013, 9, 1578-1588. \\ doi:10.3762/bjoc. 9.180 \\ Received: 15 May 2013 \\ Accepted: 10 July 2013 \\ Published: 05 August 2013 \\ Associate Editor: T. P. Yoon \\ (C) 2013 Shaikh and Hong; licensee Beilstein-Institut. \\ License and terms: see end of document.
}

\begin{abstract}
A series of general and selective Pd(II)-catalyzed Heck reactions were investigated under mild reaction conditions. The first protocol has been developed employing an imidazole-based secondary phosphine oxide (SPO) ligated palladium complex (6) as a precatalyst. The catalytic coupling of aryl halides and olefins led to the formation of the corresponding coupled products in excellent yields. A variety of substrates, both electron-rich and electron-poor olefins, were converted smoothly to the targeted products in high yields. Compared with the existing approaches employing SPO-Pd complexes in a Heck reaction, the current strategy features mild reaction conditions and broad substrate scope. Furthermore, we described the coupling of arylboronic acids with olefins, which were catalyzed by $\mathrm{Pd}(\mathrm{OAc})_{2}$ and employed $\mathrm{N}$-bromosuccinimide as an additive under ambient conditions. The resulted biaryls have been obtained in moderate to good yields.
\end{abstract}

\section{Introduction}

Substituted olefins are important structural motifs in natural products, pharmaceuticals, bioactive compounds and organic materials $[1,2]$. Olefins such as stilbene derivatives normally show antitumor [3], antiinflammatory [4], neuroprotective [5], and cardioprotective [6] properties. Due to its importance in the synthesis of leading molecules, a variety of preparative methodologies have been developed. Particularly, the Heck reaction is one of the most chosen methods in the synthesis of aryl-substituted olefins [7-9]. Aryl halides or arylboronic acids are among

the most commonly employed arylpalladium precursors in the Heck reaction.

In the early 1970s, Mizoroki [10] and Heck [11] developed a palladium(0)-catalyzed cross-coupling of olefins with organic halides. Later, several other catalytic protocols were used with variations in their coupling procedures by changing metal sources, ligands, additives or substrates [12-16]. The class of phosphine-ligated palladium complexes [17-21] represents the 
most frequently employed precatalysts to achieve high reactivities and selectivities for such reactions. However, such trisubstituted phosphines in the palladium complexes are often air-sensitive in nature and easily oxidized $[22,23]$. Therefore, a new class of secondary phosphine oxide ligands (SPO) has been explored for these ligand-assisted palladium-catalyzed crosscoupling reactions [24-27]. This type of SPO ligand is stable towards air and moisture and convenient to handle compared to the conventional trisubstituted phosphine ligands. Despite this advantage, the potential of these ligands has not been fully realized in Heck arylation reactions. Up to now, only a few examples of utilizing SPO-ligated palladium complexes in oxidative Heck reactions have been demonstrated [28-31]. Previously, we also reported the synthesis of cobalt-containing SPO ligands and their palladium complex. This was successfully applied as a catalytic precursor in oxidative Heck reactions [32]. However, these reactions were carried out at high temperatures with limited substrate scope. Therefore, the development of an alternative general and mild procedure employing a stable and inexpensive ligand is still in great demand.

Furthermore, the application of palladium complexes in the oxidative coupling of organo-boron compounds with olefins has attracted much attention in recent years [33-38]. Various catalytic systems have been developed by Jung [39] and Larhed et al. [40-43] by employing diverse variations in oxidants, ligands or palladium complexes [44-47]. Nowadays, several competent methods are also known to achieve this transformation with different reaction conditions employing base-free, ligand-free conditions or by using conventional oxidants such as oxygen, benzoquinone, $\mathrm{Cu}$ salts, etc. [48-53].

In this article we report two new protocols for Heck cross-coupling reactions: (i) a stable SPO ligated palladium complex 6 catalyzed cross-coupling of aryl halides $\mathbf{1}$ with olefins 2 at $60{ }^{\circ} \mathrm{C}$; and (ii) $\mathrm{Pd}(\mathrm{OAc})_{2}$ catalyzed arylation of arylboronic acids 4 with olefins at $25{ }^{\circ} \mathrm{C}$ (Scheme 1).

\section{Results and Discussion Heck reaction of aryl halides with olefins}

In the presence of solvents, secondary phosphine oxide $(\mathrm{RR} ' \mathrm{P}(\mathrm{O}) \mathrm{H})$ might undergo tautomerization, which generates a less stable phosphinous acid (RR'POH) species. Subsequently, its coordination to the metal center through the phosphorus atom forms a phosphinous acid-metal complex [54-56]. Thus, the resulting transition-metal complex might function as an active catalyst in various $\mathrm{C}-\mathrm{C}$-bond-forming reactions. Ackermann et al. reported the synthesis of stable $N$-aryl-substituted pyrrole and indole-derived SPO-preligands, which were utilized in Kumada-Corriu cross-coupling reactions [57]. Recently, we reported the synthesis and characterization of imidazole-based secondary phosphine oxide ligand $\mathbf{5}$ and its application in $\mathrm{C}-\mathrm{C}$ bond-forming reactions (Scheme 2) [58]. Furthermore, the application of complex 6 in cross-coupling reactions has been carefully studied. We found that complex $\mathbf{6}$ is an active catalyst for the Heck reaction of aryl halides with olefins under mild conditions.

To optimize the reaction conditions, a series of reactions under various combinations of bases, solvents and temperatures, employing complex $\mathbf{6}$ as precatalyst, was pursued. Bromobenzene (1a) and styrene (2a) were chosen as the model substrates in this coupling reaction and the results are presented in Table 1.

Initially, the coupling was carried out by using $1 \mathrm{~mol} \%$ loading of Pd-complex $\mathbf{6}$ as a precatalyst, with styrene (2a, $1 \mathrm{mmol})$, and bromobenzene (1a, $1 \mathrm{mmol})$ in DMSO $(2 \mathrm{~mL})$, and at

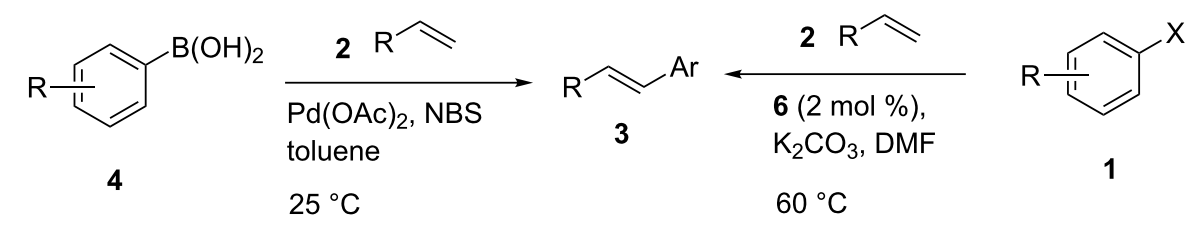

$\mathrm{R}=$ aryl, alkyl, $\mathrm{CO}_{2} \mathrm{R}^{\prime}$, etc. $\mathrm{X}=\mathrm{Cl}, \mathrm{Br}$, I.

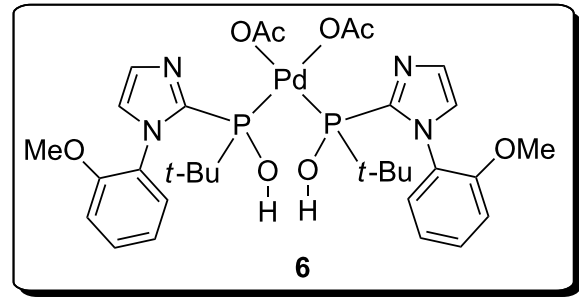




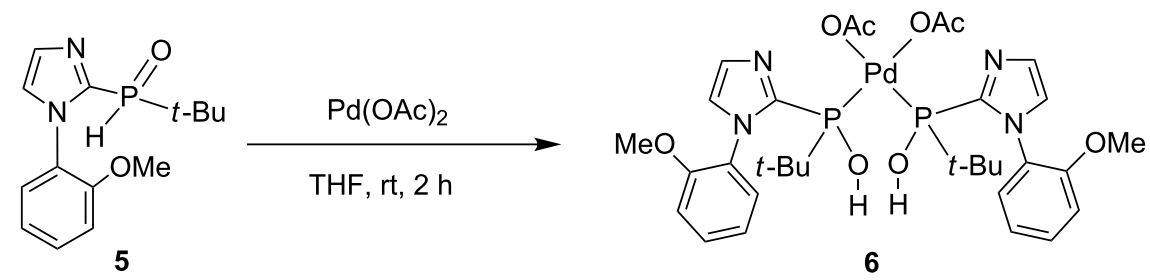

Scheme 2: Synthesis of imidazole-based SPO-Pd complex 6.

Table 1: Palladium complex (6) catalyzed Heck reaction of bromobenzene and styrene: Optimization of reaction conditions. ${ }^{a}$

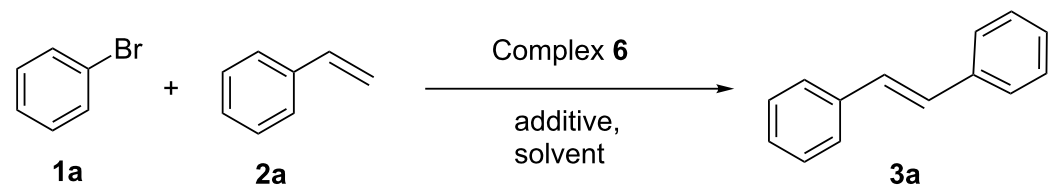

\begin{tabular}{|c|c|c|c|c|c|}
\hline Entry & Complex 6 (mol \%) & Base (equiv) & Solvent & Temp $\left({ }^{\circ} \mathrm{C}\right)$ & Yield $(\%)^{\mathrm{b}}$ \\
\hline 1 & 1 & $\mathrm{NaOH}(1)$ & DMSO & $\mathrm{rt}$ & - \\
\hline 2 & 2 & $\mathrm{NaOAc}(1)$ & DMSO & $\mathrm{rt}$ & - \\
\hline 3 & 2 & $\mathrm{Et}_{3} \mathrm{~N}(2)$ & DMSO & 40 & - \\
\hline 4 & 1 & $\mathrm{~K}_{2} \mathrm{CO}_{3}(1)$ & toluene & $\mathrm{rt}$ & - \\
\hline 5 & 1 & $\mathrm{~K}_{2} \mathrm{CO}_{3}(1)$ & $\mathrm{CH}_{3} \mathrm{CN}$ & $\mathrm{rt}$ & $-^{\mathrm{c}}$ \\
\hline 6 & 1 & $\mathrm{~K}_{3} \mathrm{PO}_{4}(1)$ & THF & 40 & 17 \\
\hline 7 & 1 & $\mathrm{~K}_{3} \mathrm{PO}_{4}(1)$ & THF & 60 & 24 \\
\hline 8 & 1 & $\mathrm{~K}_{2} \mathrm{CO}_{3}(1)$ & THF & 60 & 46 \\
\hline 9 & 1 & $\mathrm{~K}_{2} \mathrm{CO}_{3}(1)$ & DMF & 100 & 65 \\
\hline 10 & 2 & $\mathrm{~K}_{2} \mathrm{CO}_{3}(2)$ & DMF & 100 & 84 \\
\hline 11 & 2 & $\mathrm{~K}_{2} \mathrm{CO}_{3}(2)$ & DMF & 80 & 92 \\
\hline 12 & 2 & $\mathrm{~K}_{2} \mathrm{CO}_{3}(2)$ & DMF & 50 & 73 \\
\hline 13 & 2 & $\mathrm{~K}_{2} \mathrm{CO}_{3}(1)$ & DMF & 60 & 89 \\
\hline 14 & 2 & $\mathrm{~K}_{2} \mathrm{CO}_{3}(2)$ & DMF & 60 & 96 \\
\hline 15 & 2 & $\mathrm{~K}_{2} \mathrm{CO}_{3}(2)$ & no solv. & 60 & 82 \\
\hline
\end{tabular}

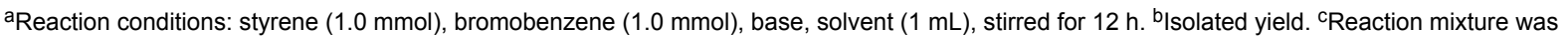
stirred for $24 \mathrm{~h}$.

ambient temperature in the presence of $\mathrm{NaOH}$ ( 1 equiv, Table 1 , entry 1). The reaction did not give the coupled product $\mathbf{3 a}$. Moreover, the use of other bases such as $\mathrm{NaOAc}, \mathrm{Et}_{3} \mathrm{~N}$ and $\mathrm{K}_{2} \mathrm{CO}_{3}$ in the presence of the solvents, DMSO, toluene or acetonitrile were not useful and no coupled product was observed. Interestingly, the reaction showed little progress in the presence of $\mathrm{K}_{3} \mathrm{PO}_{4}$ and tetrahydrofuran at $40{ }^{\circ} \mathrm{C}$ to obtain 3a in $17 \%$ yield (Table 1 , entry 6 ). The yield was slightly improved when the reaction was heated at $60{ }^{\circ} \mathrm{C}$ (Table 1 , entry 7). When $\mathrm{K}_{2} \mathrm{CO}_{3}$ (1.0 equiv) in THF was employed under similar reaction conditions, the yield of trans-stilbene was improved to $46 \%$ (Table 1 , entry 8 ). Once $\mathrm{K}_{2} \mathrm{CO}_{3}$ had been selected as the most effective base, the next step involved the enhancement of the product yield. The combination of $\mathrm{K}_{2} \mathrm{CO}_{3}$
(2 equiv) and DMF ( $2 \mathrm{~mL}$ ) resulted in the formation of $84 \%$ of 3a at $100{ }^{\circ} \mathrm{C}$ (Table 1 , entry 10). A further increase in the reaction temperature would lead to decomposition of the palladium complex, which was formed in situ, thus lowered the yield of the product. Therefore, the loading of the precatalyst 6 was increased to $2 \mathrm{~mol} \%$ and resulted in the formation of trans-stilbene in $92 \%$ yield at $80{ }^{\circ} \mathrm{C}$ (Table 1, entry 11). Synthetically, it is important to carry out reactions under mild reaction conditions. Nevertheless, low yield (73\%) of the product was obtained by reducing the reaction temperature to $50{ }^{\circ} \mathrm{C}$. Thus, a substrate survey was conducted at $60^{\circ} \mathrm{C}$. The optimized reaction conditions were found to be the use of styrene (2a, $1 \mathrm{mmol})$, bromobenzene (1a, $1 \mathrm{mmol}), \mathrm{K}_{2} \mathrm{CO}_{3}(2 \mathrm{mmol})$, and precatalyst $6(2 \mathrm{~mol} \%)$ with heating at $60{ }^{\circ} \mathrm{C}$ in DMF $(1 \mathrm{~mL}$, 
Table 1, entry 14). It is worthy of noting that the coupling reaction was also performed in the absence of solvent, which gave $82 \%$ yield (Table 1 , entry 15 ) of the coupled product.

A wide range of olefins with different and diversely substituted aryl bromides were subjected to cross-coupling to produce the corresponding 1,2-disubstituted olefins. The results are summarized in Table 2.
Both aryl bromide and aryl iodide performed well (Table 2, entries 1 and 2) under these conditions. However, the aryl chloride was found to be less reactive giving the corresponding product $3 \mathrm{a}$ in $62 \%$ yield (Table 2 , entry 3 ). The oxidative coupling was found to be selective in the case of 4-bromostyrene (2b), which gives $90 \%$ yield of 4 -bromo trans-stilbene (3b) without the observation of any side product (Table 2, entry 4). The presence of either an electron-withdrawing or electron-

Table 2: Heck reaction of olefins and aryl halides: Scope of substrate. ${ }^{a}$

Entry

1

4

5

6

7

8

9

10

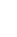

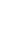

Olefin (2)<smiles>C=Cc1ccccc1</smiles>

2a<smiles>C=Cc1ccccc1</smiles>

$2 a$<smiles>C=Cc1ccccc1</smiles>

2a<smiles>C=Cc1ccc(Br)cc1</smiles>

2b<smiles>C=Cc1ccc(C)cc1</smiles>

2c<smiles>C=Cc1ccccc1</smiles>

$2 a$<smiles>C=Cc1cccc([N+](=O)[O-])c1</smiles>

2d<smiles>C=Cc1ccc(OC)cc1</smiles>

$2 e$<smiles>C=Cc1ccc2ccccc2c1</smiles>

$2 f$<smiles>C=Cc1ccc(CO)cc1</smiles>

Aryl halide (1)

Product (3)

Yield (\%),<smiles>C(=Cc1ccccc1)c1ccccc1</smiles>

$3 a$<smiles>C(=C/c1ccccc1)\c1ccccc1</smiles>

3a<smiles>C(=Cc1ccccc1)c1ccccc1</smiles>

$3 a$<smiles>Brc1ccc(/C=C/c2ccccc2)cc1</smiles>

$3 b$<smiles>Cc1ccc(/C=C/c2ccccc2)cc1</smiles>

$3 c$<smiles>C(=C/c1ccc2ccccc2c1)\c1ccccc1</smiles>

3d<smiles>O=[N+]([O-])c1cccc(/C=C/c2ccccc2)c1</smiles>

$3 e$<smiles>COc1ccc(/C=C/c2ccccc2)cc1</smiles>

$3 f$<smiles>C(=Cc1ccc2ccccc2c1)c1ccccc1</smiles>

3d<smiles>OCc1ccc(/C=C/c2ccccc2)cc1</smiles>

96

98

62

91 
Table 2: Heck reaction of olefins and aryl halides: Scope of substrate. ${ }^{a}$ (continued)

11<smiles>C=Cc1ccc(C=O)cc1</smiles>

$2 \mathrm{~h}$

12<smiles>C=Cc1ccc(C(C)=O)cc1</smiles>

2i

13<smiles>C=Cc1ccc(C#N)cc1</smiles>

2j

14<smiles>C=Cc1ccc(C(F)(F)F)cc1</smiles>

2k

15<smiles>C=Cc1cccc(C)c1</smiles>

2I

16<smiles>C=Cc1ccccc1</smiles>

2a

17<smiles>C=Cc1ccccn1</smiles>

$2 \mathrm{~m}$<smiles>C=CC(=O)OCCCC</smiles>

2n

19<smiles>C=CC(=O)OCC</smiles>

20

20<smiles>C=CC(=O)OC</smiles>

$2 p$<smiles>Brc1ccccc1</smiles>

1a<smiles>Brc1ccccc1</smiles>

1a<smiles>Brc1ccccc1</smiles>

1a<smiles>Brc1ccccc1</smiles>

1a<smiles>Brc1ccccc1</smiles>

1a<smiles>Cc1cc(C)cc(Br)c1</smiles>

$1 e$<smiles>Brc1ccccc1</smiles>

$1 a$<smiles>Brc1ccccc1</smiles>

1a<smiles>Brc1ccccc1</smiles>

1a<smiles>Brc1ccccc1</smiles>

1a<smiles>O=Cc1ccc(/C=C/c2ccccc2)cc1</smiles>

85

$3 \mathrm{~h}$<smiles>CC(=O)c1ccc(C=Cc2ccccc2)cc1</smiles>

87

$3 \mathbf{i}$<smiles>N#Cc1ccc(/C=C/c2ccccc2)cc1</smiles>

3j<smiles>FC(F)(F)c1ccc(/C=C/c2ccccc2)cc1</smiles>

3k<smiles>Cc1cccc(/C=C/c2ccccc2)c1</smiles>

3I<smiles>Cc1cc(C)cc(C=Cc2ccccc2)c1</smiles>

$3 n$<smiles>CCC(C)OC(=O)/C=C/c1ccccc1</smiles>

95

30<smiles>CCOC(=O)/C=C/c1ccccc1</smiles>

$3 p$<smiles>COC(=O)/C=C/c1ccccc1</smiles>

$3 q$

aReaction conditions: olefin (1.0 mmol), aryl halide $(1.0 \mathrm{mmol}), \mathrm{Pd}-\mathrm{complex} 6(2.0 \mathrm{~mol} \%), \mathrm{K}_{2} \mathrm{CO}_{3}(2.0 \mathrm{mmol}), \mathrm{DMF}(1 \mathrm{~mL}), 6{ }^{\circ} \mathrm{C}, 12 \mathrm{~h} .{ }^{\mathrm{b}} / \mathrm{solated}$ yield. ${ }^{C}$ Products were characterized by ${ }^{1} \mathrm{H},{ }^{13} \mathrm{C}$ NMR and GC-MS. ${ }^{\mathrm{d}}$ The yield corresponds to employing 4-chloro anisole as the aryl halide source.

donating group on the aromatic ring of olefin did not affect the reactivity and yield of product. The reactions led to the formation of excellent yields of the corresponding products $\mathbf{3 e}$ and $\mathbf{3 f}$ in $90 \%$ and $95 \%$ yields, respectively (Table 2, entries 7 and 8 ). As known, aromatic rings having substituents such as, $-\mathrm{CH}_{2} \mathrm{OH}$, $-\mathrm{CHO},-\mathrm{COCH}_{3}-\mathrm{CN}$ and $-\mathrm{CF}_{3}$ are rather useful in organic syn- 
thesis. However, in earlier reported oxidative coupling conditions these functional groups were not compatible and gave low yields of products. Therefore, these highly modifiable groups were screened under these catalytic conditions. Thus, 4-vinylbenzyl alcohol (2g), 4-vinyl benzaldehyde (2h), 4-vinylacetophenone (2i), 4-cyanostyrene (2j) and 4-trifluoromethylstyrene (2k) were smoothly converted to their corresponding coupled products $\mathbf{3 g}-\mathbf{3 k}$ in excellent yields (Table 2, entries 10-14). The selectivities and yields of the coupled products were excellent regardless of ortho-, meta-, or para-substitution patterns on either styrenes or aryl halides under these catalytic conditions. For example, the coupling of substituted methylstyrenes (Table 2, entry 15) or alkyl-substituted aryl halides (Table 2, entry 16) gave $88-90 \%$ isolated yields of $\mathbf{3 l}$ and $\mathbf{3 m}$. To investigate whether the reaction was compatible with a heteroaryl olefin, 2-vinylpyridine (2m) was subjected to this reaction. It produced the corresponding coupled product $\mathbf{3 n}$ in $78 \%$ yield (Table 2, entry 17). Furthermore, using these optimized conditions, bromobenzene (1a) was examined with different vinyl esters to determine the scope of this procedure. The results are given in Table 2, entries 18-20. Notably, the performances were in agreement with the previous expectations and yields are excellent in the preparation of $\alpha, \beta$-unsaturated esters. The corresponding $\alpha, \beta$-unsaturated esters $\mathbf{3 0}-\mathbf{3 q}$ were obtained in $90-95 \%$ yields, respectively.

\section{Heck reaction of arylboronic acids with olefins}

The phosphine- and base-free coupling of arylboronic acids with olefins under mild reaction conditions were studied as well to broaden the scope of cross-coupling reactions. To search for the optimized reaction conditions, phenylboronic acid (4a) and styrene (2a) were chosen as the model substrates and $\mathrm{Pd}(\mathrm{OAc})_{2}$ was employed as the catalyst. Various reaction conditions were tested and the results are presented in Table 3. Initially, a $\mathrm{Pd}(\mathrm{OAc})_{2}$ catalyzed Heck reaction was performed employing polar sovents, dimethylacetamide (DMAc) and DMF, at $25^{\circ} \mathrm{C}$ in the presence of 0.5 equiv of $N$-bromosuccinimide (NBS). This resulted in the formation of trans-stilbene (3a) in 52\% and $40 \%$ yield, respectively (Table 3 , entries 1 and 2 ). However, the same reaction under the control conditions (i.e., in the absence of NBS) resulted in production of a trace amount of the coupled product 3a (Table 3, entry 3). When the coupling reaction was carried out at $90^{\circ} \mathrm{C}$ in DMAc solvent, the yield of 3a decreased, due to the formation of side product, such as bromobenzene, from the corresponding phenylboronic acid (Table 3, entry 4). Therefore, it is believed that NBS plays an important role in this catalytic reaction. Furthermore, we focused our attention to other solvents such as $\mathrm{MeOH}, \mathrm{CH}_{2} \mathrm{Cl}_{2}, \mathrm{CH}_{3} \mathrm{CN}, \mathrm{Me}_{2} \mathrm{O}, t-\mathrm{Bu}_{2} \mathrm{O}$, THF, DMSO and 1,4-dioxane, which resulted in low yields of arylated product. Subsequently, the reaction was subjected to

Table 3: Heck reaction of phenylboronic acid and styrene: Optimization of the reaction conditions. ${ }^{a}$

\begin{tabular}{|c|c|c|c|c|c|}
\hline & $4 a$ & $\begin{array}{r}\mathrm{Ph}^{\curvearrowright} \\
2 \mathrm{a}\end{array}$ & $\begin{array}{l}\mathrm{Pd}(\mathrm{OAc})_{2}, \\
\begin{array}{l}\text { additive, } \\
\text { solvent }\end{array}\end{array}$ & $3 \mathbf{a}$ & \\
\hline Entry & Additive (equiv) & Solvent & Time $(h)$ & Temp. $\left({ }^{\circ} \mathrm{C}\right)$ & Yield $(\%)^{b, c}$ \\
\hline 1 & NBS (0.5) & DMAc & 18 & 25 & 52 \\
\hline 2 & NBS (0.5) & DMF & 18 & 25 & 40 \\
\hline 3 & - & DMAc & 24 & 25 & trace \\
\hline 4 & NBS (0.5) & DMAc & 18 & 90 & 34 \\
\hline 5 & NBS (0.5) & toluene & 18 & 25 & 68 \\
\hline 6 & NBS (0.5) & toluene & 24 & 25 & 69 \\
\hline 7 & NBS (0.1) & toluene & 18 & 25 & 30 \\
\hline 8 & NBS (0.1) & toluene & 18 & 80 & 47 \\
\hline 9 & NBS (1) & toluene & 18 & 25 & 40 \\
\hline 10 & NBS (0.3) & toluene & 12 & 25 & 76 \\
\hline 11 & $\mathrm{NBS} / \mathrm{K}_{2} \mathrm{CO}_{3}(0.3: 1)$ & toluene & 18 & 25 & $n r^{d}$ \\
\hline 12 & NBS/4 A MS (0.3:2) & toluene & 12 & 25 & 15 \\
\hline 13 & $\operatorname{LiBr}(0.3)$ & toluene & 12 & 25 & $\mathrm{nr}$ \\
\hline 14 & $\mathrm{CuBr}$ & toluene & 12 & 25 & 42 \\
\hline
\end{tabular}

${ }^{a}$ Reaction conditions: styrene $(0.5 \mathrm{mmol})$, phenylboronic acid $(0.5 \mathrm{mmol}), \mathrm{Pd}(\mathrm{OAc})_{2}(5 \mathrm{~mol} \%)$, additive and dry solvent $(1 \mathrm{~mL})$ for $12 \mathrm{~h}$ at $25^{\circ} \mathrm{C}$. b Isolated yield. ${ }^{C}$ Product was characterized by GC-MS, ${ }^{1} \mathrm{H}$ and ${ }^{13} \mathrm{C}$ NMR. ${ }^{\mathrm{d}}$ Reaction was stirred under air. 
the apolar solvent toluene. The expected product trans-stilbene (3a) was obtained in $68 \%$ yield at $25{ }^{\circ} \mathrm{C}$ for $18 \mathrm{~h}$ (Table 3 , entry 5). The yield of the desired product did not improve even when the reaction was stirred for $24 \mathrm{~h}$ (Table 3, entry 6). On the other hand, lowering the additive (NBS) to $10 \mathrm{~mol} \%$ did not show any improvement to the formation of trans-stilbene (3a) (Table 3, entries 7 and 8). A sharp decline in the formation of trans-stilbene (3a) (Table 3, entry 9) was observed on increasing the quantity of NBS to a stoichiometric amount (1.0 equiv). This was probably due to the formation of other competitive side product(s). Interestingly, the coupled product was obtained with improved yield of $76 \%$ by using $30 \mathrm{~mol} \%$ NBS (Table 3, entry 10). Next, we turned our attention to the improvement of the yields of trans-stilbene by adjusting other reaction parameters. Thus, the addition of $\mathrm{K}_{2} \mathrm{CO}_{3}$ as base along with NBS under similarly performed reaction conditions led to no formation of the targeted product. The addition of molecular sieves was not a good choice either [59]. The other additives such as $\mathrm{LiBr}$ and $\mathrm{CuBr}$ were also examined. Still, no coupled product was obtained in the presence of $\mathrm{LiBr}(30 \mathrm{~mol} \%$, Table 3, entry 13). On the other hand, the employment of $\mathrm{CuBr}$ $(30 \mathrm{~mol} \%)$ with the presence of $\mathrm{Pd}(\mathrm{OAc})_{2}$ resulted in a $42 \%$ yield of trans-stilbene (3a) (Table 3, entry 14). Thus, the optimized reaction conditions for the Heck reaction here is the use of arylboronic acid $(1 \mathrm{mmol})$, olefin $(1 \mathrm{mmol}), \mathrm{Pd}(\mathrm{OAc})_{2}$ $(5 \mathrm{~mol} \%)$, NBS $(30 \mathrm{~mol} \%)$, toluene $(1 \mathrm{~mL})$ at $25^{\circ} \mathrm{C}$ under stirring for $12 \mathrm{~h}$.

The optimized Heck cross-coupling conditions were employed to examine the arylation of substituted olefins and phenylboronic acid. The results are presented in Table 4. As shown in Table 4, this coupling procedure tolerates various functional groups to afford the desired product (3). The compatibility of halo-substituted styrenes is synthetically useful since the products could be easily modified further to form synthetic building blocks. Thus, the coupling of 4-fluorostyrene (2q), 4-bromostyrene (2b) and 4-chlorostyrene (2r) through oxidative Heck reaction led to the corresponding products in $65-69 \%$ yields, respectively (Table 4, entries 2-4). Furthermore, the electronwithdrawing groups on styrene, such as 3-nitrostilbene (2d) and 4-trifluorostilbene $(\mathbf{2 k})$ resulted in the formation $\mathbf{3 e}$ and $\mathbf{3 k}$ in $76 \%$ and $70 \%$ yields, respectively (Table 4 , entries 5 and 6 ). However, the electron-donating substituent on olefin lessened the reaction rate and thus led to poor yield of product $\mathbf{3 f}$

Table 4: Substrate scope in the Heck arylation reaction of phenylboronic acids with olefins. ${ }^{\text {a }}$

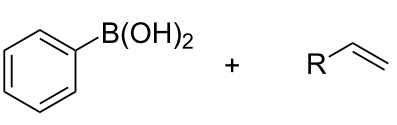

$4 a$
2

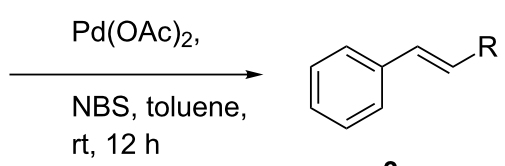

3

\begin{tabular}{|c|c|c|c|}
\hline Entry & Substrate (2) & Product $(3)^{b}$ & Yield $(\%)^{c}$ \\
\hline 1 & $2 a$ & $3 a$ & 76 \\
\hline 2 & $2 q$ & $3 r$ & $65^{d}$ \\
\hline 3 & $2 b$ & $3 b$ & 69 \\
\hline 4 & $\mathbf{2 r}$ & $3 s$ & 66 \\
\hline 5 & $\begin{array}{r}\mathrm{NO}_{2} \\
2 \mathrm{~d}\end{array}$ & $\mathrm{NO}_{3}$ & 76 \\
\hline
\end{tabular}


Table 4: Substrate scope in the Heck arylation reaction of phenylboronic acids with olefins. ${ }^{\text {a }}$ (continued)

6<smiles>C=Cc1ccc(C(F)(F)F)cc1</smiles>

2k

7

8<smiles>C=Cc1ccc(OC)cc1</smiles>

$2 \mathrm{e}$<smiles>C=Cc1ccc(C)cc1</smiles>

9<smiles>C=CC(=O)OCCC</smiles>

2n

10<smiles>C=CC(=O)OCC</smiles>

20

11<smiles>C=CCOC(C)=O</smiles>

2s

12<smiles>FC(F)(F)c1ccc(/C=C/c2ccccc2)cc1</smiles>

3k<smiles>COc1ccc(/C=C/c2ccccc2)cc1</smiles>

$3 \mathbf{f}$<smiles>Cc1ccc(/C=C/c2ccccc2)cc1</smiles>

30<smiles>CCOC(=O)/C=C/c1ccccc1</smiles>

$3 p$<smiles>CC(=O)OC/C=C/c1ccccc1</smiles>

$3 t$

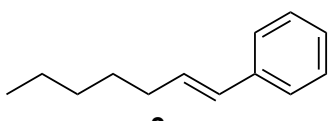

$3 u$<smiles>CCCCOC(=O)/C=C/c1ccccc1</smiles>

$44^{e}$

aReaction conditions: styrene $(1.0 \mathrm{mmol})$, phenylboronic acid $(1.0 \mathrm{mmol})$, catalyst $(5 \mathrm{~mol} \%), \mathrm{N}$-bromosuccinimide $(30 \mathrm{~mol} \%)$, and toluene $(2 \mathrm{~mL})$ under nitrogen for $12 \mathrm{~h}$. b Product was characterized by GC-MS, ${ }^{1} \mathrm{H}$ and ${ }^{13} \mathrm{C}$ NMR. Clsolated yield. ${ }^{\mathrm{d}}$ Determined by GC-MS. ${ }^{\mathrm{e}} \mathrm{E} / \mathrm{Z}$ ratio $20: 1$ by ${ }^{1} \mathrm{H}$ NMR, terminal/internal $4 / 1$.

(Table 4, entry 7). The reaction with aliphatic alkenes, such as tert-butyl acrylate (2n) or ethyl acrylate (2o), allyl acetate (2s) and $n$-heptene (2t) afforded the corresponding coupled products in moderate yields, respectively (Table 4, entries 9-12).
To expand the scope of this cross-coupling, these conditions were then applied to a variety of boronic acids and styrene (Table 5). For a diverse set of boronic acids, cross-coupling proceeded smoothly with $\mathbf{2 a}$ in moderate to good yields. In this

Table 5: Substrate scope in Heck arylation reaction of phenylboronic acids with olefins. ${ }^{a}$

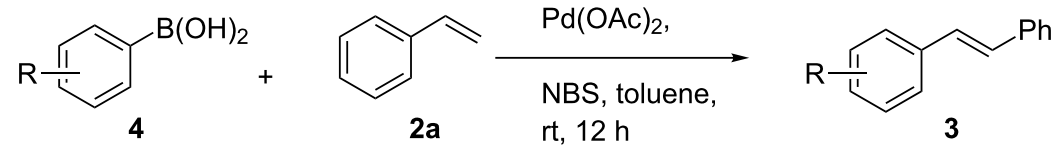

Entry Substrate


Table 5: Substrate scope in Heck arylation reaction of phenylboronic acids with olefins. ${ }^{\text {a }}$ (continued)

2<smiles>Oc1ccc(Br)cc1</smiles>

$4 b$

3<smiles>Cc1ccc(Br)cc1</smiles>

4<smiles></smiles>

4d

5<smiles>O=[N+]([O-])c1ccc(Br)cc1</smiles>

$4 \mathrm{e}$<smiles>O=[N+]([O-])c1cccc(Br)c1</smiles>

$4 f$<smiles>COc1cccc(C)c1</smiles>

$4 \mathrm{~g}$

8<smiles>Clc1ccc(Br)cc1</smiles>

$4 h$

9<smiles>COc1ccc([SeH])cc1</smiles>

$4 i$<smiles>Brc1ccc(/C=C/c2ccccc2)cc1</smiles>

$3 b$<smiles>Cc1ccc(/C=C/c2ccccc2)cc1</smiles><smiles>FC(F)(F)c1ccc(/C=C/c2ccccc2)cc1</smiles>

$3 k$<smiles>O=[N+]([O-])c1ccc(/C=C/c2ccccc2)cc1</smiles>

3v<smiles>O=[N+]([O-])c1cccc(/C=C/c2ccccc2)c1</smiles>

$3 s$<smiles>COc1ccc(/C=C/c2ccccc2)cc1</smiles>

40

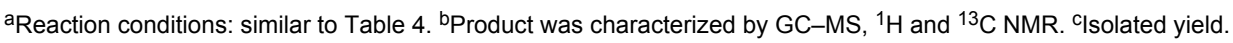

case, the procedure also tolerated a range of functional groups, such as bromo, chloro, nitro, methoxy, and alkyl groups. The arylboronic acids with electron-withdrawing substituents furnished good yields of coupled product as compared to the electron-donating substituents. For example, 4-nitro (4e) and 3-nitrophenylboronic acid (4f) were reacted smoothly with styrene to afford the corresponding products in $75 \%$ and $73 \%$ yields, respectively (Table 5, entries 5 and 6).

\section{Conclusion}

In summary, we have developed two new protocols for oxidative Heck reactions employing $\mathrm{Pd}(\mathrm{OAc})_{2}$ as a catalytic precursor. The first method is based on coupling between various olefins and aryl halides utilizing an imidazole-based secondary phosphine oxide ligated palladium complex (6) under mild conditions. The yields of products obtained were excellent and in high regioselectivity. Compared with the previously described procedures for the Heck reaction of aryl halides as substrates employing a SPO-Pd complex as a catalyst, the method reported here has the advantages of having a stable catalyst system, general substrate scope, and mild reaction conditions $\left(60^{\circ} \mathrm{C}\right)$. Secondly, we also developed the Heck reaction of arylboronic acids with various alkenes employing $\mathrm{N}$-bromosuccinimide as an additive and catalyzed by $\mathrm{Pd}(\mathrm{OAc})_{2}$, under base- and ligand-free conditions at $25^{\circ} \mathrm{C}$. The yields of the coupled products are moderate to good. 


\section{Supporting Information}

\section{Supporting Information File 1}

General procedure for Heck reactions, preparation of

complex 6 and characterization data.

[http://www.beilstein-journals.org/bjoc/content/

supplementary/1860-5397-9-180-S1.pdf]

\section{Acknowledgements}

The authors are grateful to the National Science Council of Taiwan (Grant NSC 101-2113-M-005-011-MY3) for financial support.

\section{References}

1. Douney, A. M.; Overman, L. E. Chem. Rev. 2003, 103, 2945-2963. doi:10.1021/cr020039h

2. Nicolaou, K. C.; Bulger, P. G.; Sarlah, D. Angew. Chem., Int. Ed. 2005, 44, 4442-4489. doi:10.1002/anie.200500368

3. Jang, M.; Cai, L.; Udeani, G. O.; Slowing, K. V.; Thomas, C. F.; Beecher, C. W. W.; Fong, H. H. S.; Farnsworth, N. R.; Kinghorn, A. D.; Mehta, R. G.; Moon, R. C.; Pezzuto, J. M. Science 1997, 275 , 218-220. doi:10.1126/science.275.5297.218

4. Elmali, N.; Baysal, O.; Harma, A.; Esenkaya, I.; Mizrak, B. Inflammation 2007, 30, 1-6. doi:10.1007/s10753-006-9012-0

5. Karuppagounder, S. S.; Pinto, J. T.; Xu, H.; Chen, L.-H.; Beal, M. F.; Gibson, G. E. Neurochem. Int. 2009, 54, 111-118. doi:10.1016/j.neuint.2008.10.008

6. Gurusamy, N.; Lekli, I.; Mukherjee, S.; Ray, D.; Ahsan, M. K.; Gherghiceanu, M.; Popescu, L. M.; Das, D. K. Cardiovasc. Res. 2010, 86, 103-112. doi:10.1093/cvr/cvp384

7. Tsuji, J. Palladium Reagents and Catalysts: Innovations in Organic Synthesis; Wiley: Chichester, U.K., 1995.

8. Bräse, S.; de Meijere, A. Cross-Coupling of Organyl Halides with Alkenes: the Heck Reaction. In Metal-Catalyzed Cross-Coupling Reactions; Diederich, F.; Stang, P. J., Eds.; Wiley-VCH: Weinheim, Germany, 1998

9. Sehnal, P.; Taylor, R. J. K.; Fairlamb, I. J. S. Chem. Rev. 2010, 110, 824-889. doi:10.1021/cr9003242

10. Mizoroki, T.; Mori, K.; Ozaki, A. Bull. Chem. Soc. Jpn. 1971, 44, 581. doi:10.1246/bcsj.44.581

11. Heck, R. F.; Nolley, J. P. J. Org. Chem. 1972, 37, 2320-2322. doi:10.1021/jo00979a024

12. Crisp, G. T. Chem. Soc. Rev. 1998, 27, 427-436. doi:10.1039/a827427z

13. Link, J. T.; Overman, L. E. Intramolecular Heck Reactions in Natural Product Chemistry. In Metal-Catalyzed Cross-Coupling Reactions; Diedrich, F.; Stang, P. J., Eds.; Wiley-VCH: Weinheim, Germany, 1998.

14. Beletskaya, I.; Cheprakov, A. V. Chem. Rev. 2000, 100, 3009-3066. doi:10.1021/cr9903048

15. Liu, L.-j.; Wang, F.; Wang, W.; Zhao, M.-x.; Shi, M. Beilstein J. Org. Chem. 2011, 7, 555-564. doi:10.3762/bjoc.7.64

16. Grasa, G. A.; Singh, R.; Stevens, E. D.; Nolan, S. P. J. Organomet. Chem. 2003, 687, 269-279. doi:10.1016/S0022-328X(03)00375-9

17. Ozawa, F.; Kubo, A.; Hayashi, T. Chem. Lett. 1992, 2177-2180. doi:10.1246/cl.1992.2177
18. Littke, A. F.; Fu, G. C. J. Org. Chem. 1999, 64, 10-11. doi:10.1021/jo9820059

19. Stambuli, J. P.; Stauffer, S. R.; Shaughnessy, K. H.; Hartwig, J. F. J. Am. Chem. Soc. 2001, 123, 2677-2678. doi:10.1021/ja0058435

20. Hansen, A. L.; Ebran, J.-P.; Ahlquist, M.; Norrby, P.-O.; Skrydstrup, T. Angew. Chem., Int. Ed. 2006, 45, 3349-3353. doi:10.1002/anie.200600442

21. Fleckenstein, C. A.; Plenio, H. Chem. Soc. Rev. 2010, 39, 694-711. doi:10.1039/b903646f

22. Parshall, G. W.; Ittel, S. D. Homogeneous Catalysis; J. Wiley and Sons: New York, 1992.

23. Albéniz, A. C.; Carrera, N. Eur. J. Inorg. Chem. 2011, 2347-2360. doi:10.1002/ejic.201100162

24. Li, G. Y. Angew. Chem., Int. Ed. 2001, 40, 1513-1516. doi:10.1002/1521-3773(20010417)40:8<1513::AID-ANIE1513>3.0.CO; 2-C

25. Jiang, X.-b.; Minnaard, A. J.; Feringa, B. L.; de Vries, J. G. J. Org. Chem. 2004, 69, 2327-2331. doi:10.1021/jo035487j

26. Ackermann, L.; Born, R. Angew. Chem., Int. Ed. 2005, 44, 2444-2447. doi:10.1002/anie.200462371

27. Xu, H.; Ekoue-Kovi, K.; Wolf, C. J. Org. Chem. 2008, 73, 7638-7650. doi:10.1021/j0801445y

28. Ackermann, L.; Potukuchi, H. K.; Kapdi, A. R.; Schulzke, C. Chem.-Eur. J. 2010, 16, 3300-3303. doi:10.1002/chem.201000032

29. Li, G. Y.; Zheng, G.; Noonan, A. F. J. Org. Chem. 2001, 66, 8677-8681. doi:10.1021/jo010764c

30. Wolf, C.; Lerebours, R. J. Org. Chem. 2003, 68, 7077-7084. doi:10.1021/jo034758n

31. Punji, B.; Mague, J. T.; Balakrishna, M. S. Inorg. Chem. 2007, 46, 11316-11327. doi:10.1021/ic701674x

32. Wei, C.-H.; Wu, C.-E.; Huang, Y.-L.; Kultyshev, R. G.; Hong, F.-E. Chem.-Eur. J. 2007, 13, 1583-1593. doi:10.1002/chem.200601051

33. Dieck, H. A.; Heck, R. F. J. Org. Chem. 1975, 40, 1083-1090. doi:10.1021/jo00896a020

34. Hayashi, T.; Yamasaki, K. Chem. Rev. 2003, 103, 2829-2844. doi:10.1021/cr020022z

35. Itoh, T.; Mase, T.; Nishikata, T.; Iyama, T.; Tachikawa, H.; Kobayashi, Y.; Yamamoto, Y.; Miyaura, N. Tetrahedron 2006, 62, 9610-9621. doi:10.1016/j.tet.2006.07.075

36. Vandyck, K.; Mattys, B.; Willen, M.; Robeyns, K.; Van Meervelt, L.; Van der Eycken, J. Org. Lett. 2006, 8, 363-366. doi:10.1021/ol0522788

37. Bazin, M.-A.; El Kihel, L.; Lancelot, J.-C.; Rault, S. Tetrahedron Lett. 2007, 48, 4347-4351. doi:10.1016/j.tetlet.2007.04.114

38. Motokura, K.; Hashimoto, N.; Hara, T.; Mitsudome, T.; Mizugaki, T.; Jitsukawa, K.; Kaneda, K. Green Chem. 2011, 13, 2416-2422. doi:10.1039/c1gc15146k

39. Yoo, K. S.; Park, C. P.; Yoon, C. H.; Sakaguchi, S.; O’Neill, J.; Jung, K. W. Org. Lett. 2007, 9, 3933-3935. doi:10.1021/ol701584f

40. Andappan, M. M. S.; Nilsson, P.; Larhed, M. Chem. Commun. 2004, 218-219. doi:10.1039/b311492a

41. Lindh, J.; Sävmarker, J.; Nilsson, P.; Sjöberg, P. J. R.; Larhed, M. Chem.-Eur. J. 2009, 15, 4630-4636. doi:10.1002/chem.200802744

42. Odell, L. R.; Lindh, J.; Gustafsson, T.; Larhed, M. Eur. J. Org. Chem. 2010, 2270-2274. doi:10.1002/ejoc.201000063

43. Nordqvist, A.; Björkelid, C.; Andaloussi, M.; Jansson, A. M.; Mowbray, S. L.; Karlén, A.; Larhed, M. J. Org. Chem. 2011, 76, 8986-8998. doi:10.1021/jo201715x 
44. Likhar, P. R.; Roy, M.; Roy, S.; Subhas, M. S.; Kantam, M. L.; Sreedhar, B. Adv. Synth. Catal. 2008, 350, 1968-1974.

doi:10.1002/adsc.200800329

45. Delcamp, J. H.; Brucks, A. P.; White, M. C. J. Am. Chem. Soc. 2008, 130, 11270-11271. doi:10.1021/ja804120r

46. Leng, Y.; Yang, F.; Wei, K.; Wu, Y. Tetrahedron 2010, 66, 1244-1248. doi:10.1016/j.tet.2009.12.027

47. Sakaguchi, S.; Yoo, K. S.; O'Neill, J.; Lee, J. H.; Stewart, T.; Jung, K. W. Angew. Chem., Int. Ed. 2008, 47, 9326-9329. doi:10.1002/anie.200803793

48. Ruan, J.; Li, X.; Saidi, O.; Xiao, J. J. Am. Chem. Soc. 2008, 130 , 2424-2425. doi:10.1021/ja0782955

49. Gottumukkala, A. L.; Teichert, J. F.; Heijnen, D.; Eisink, N.; Van Dijk, S.; Ferrer, C.; van den Hoogenband, A.; Minnaard, A. J. J. Org. Chem. 2011, 76, 3498-3501. doi:10.1021/jo101942f

50. Li, T.; Qu, X.; Zhu, Y.; Sun, P.; Yang, H.; Shan, Y.; Zhang, H.; Liu, D.; Zhang, X.; Mao, J. Adv. Synth. Catal. 2011, 353, 2731-2738. doi:10.1002/adsc.201100238

51. Werner, E. W.; Sigman, M. S. J. Am. Chem. Soc. 2010, 132, 13981-13983. doi:10.1021/ja1060998

52. Sun, P.; Zhu, Y.; Yang, H.; Yan, H.; Lu, L.; Zhang, X.; Mao, J. Org. Biomol. Chem. 2012, 10, 4512-4515. doi:10.1039/c2ob25462j

53. Mino, T.; Koizumi, T.; Suzuki, S.; Hirai, K.; Kajiwara, K.; Sakamoto, M.; Fujita, T. Eur. J. Org. Chem. 2012, 678-680. doi:10.1002/ejoc.201101533

54. Dubrovina, N. V.; Borner, A. Angew. Chem., Int. Ed. 2004, 43, 5883-5886. doi:10.1002/anie.200460848

55. Ackermann, L. Isr. J. Chem. 2010, 50, 652-663. doi:10.1002/ijch.201000043

56. Shaikh, T. M.; Weng, C.-M.; Hong, F.-E. Coord. Chem. Rev. 2012, 256 , 771-803. doi:10.1016/j.ccr.2011.11.007

57. Ackermann, L.; Kapdi, A. R.; Schulzke, C. Org. Lett. 2010, 12, 2298-2301. doi:10.1021/ol100658y

58. Hu, D.-F.; Weng, C.-M.; Hong, F.-E. Organometallics 2011, 30 , 1139-1147. doi:10.1021/om101132t

59. Zhang, Y.; Xing, H.; Xie, W.; Wan, X.; Lai, Y.; Ma, D. Adv. Synth. Catal. 2013, 355, 68-72. doi:10.1002/adsc.201200782

\section{License and Terms}

This is an Open Access article under the terms of the Creative Commons Attribution License

(http://creativecommons.org/licenses/by/2.0), which permits unrestricted use, distribution, and reproduction in any medium, provided the original work is properly cited.

The license is subject to the Beilstein Journal of Organic Chemistry terms and conditions:

(http://www.beilstein-journals.org/bjoc)

The definitive version of this article is the electronic one which can be found at: doi:10.3762/bjoc. 9.180 